\title{
Human Rights in the UK Media:
and Reality, 19 September 2014
}

\author{
BETHANY RODGERS University of Liverpool
}

With thanks to Modern Law Review support, Dr Michelle Farrell and the Human Rights and International Law Unit of the University of Liverpool Law School hosted a one day seminar, 'Human Rights in the UK Media: Representation and Reality' on 19 September, 2014. The diverse collection of papers offered legal and journalistic perspectives on the difficulties in relaying human rights in the media. This made for a fascinating day highlighting the recurring themes of the relationship
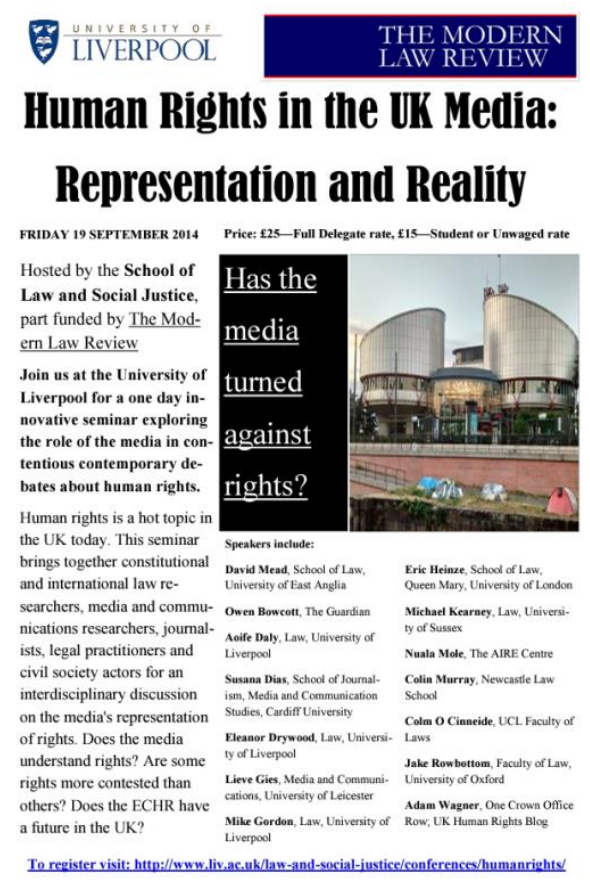
between the media and rights that developed through the panels. The seminar sought to answer a range of questions including; 'What is the nature of the representation of rights today? Is there an accurate understanding of the law, the Human Rights Act, the European Convention on Human Rights and the European Court of Human Rights? What is the appeal of rights language in media reporting?'

David Mead, Professor of UK Human Rights Law from the University of East Anglia delivered an engaging keynote entitled, 'They offer you a feature on stockings and suspenders next to a call for stiffer penalties for sex offenders: do we learn more about the media than about human rights from tabloid coverage of human rights?' ${ }^{1}$ The title is taken from 'It Says Here' by the Bark of Barking, Billy Bragg, and Mead recalled that, coincidentally, it was almost thirty years to the day since he had used the same

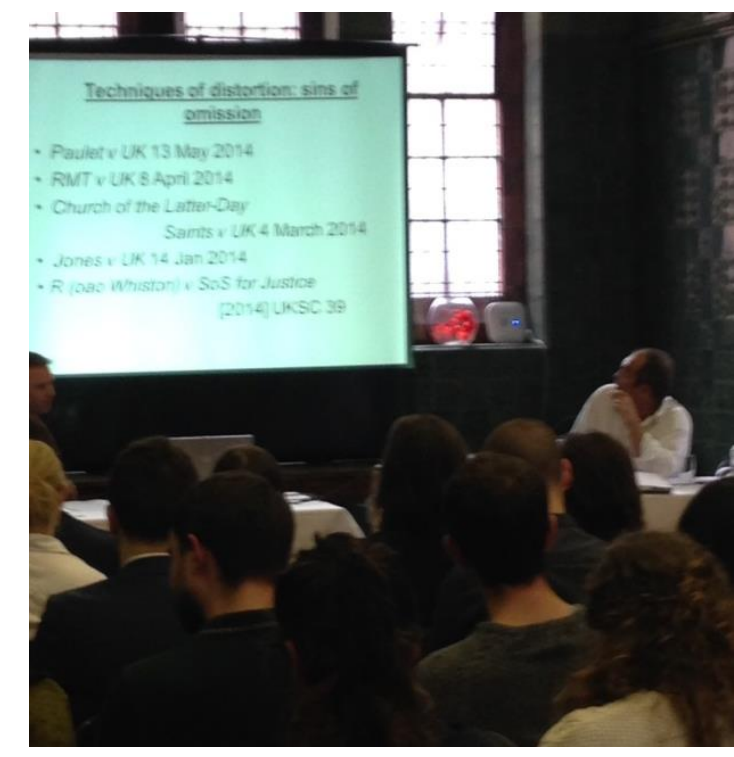

Keynote Prof Mead. Copyright Natasha Graham, University of Liverpool.

\footnotetext{
${ }^{1}$ See: http://protestmatters.wordpress.com/2014/09/22/they-offer-you-a-feature-on-stockings-and-suspenders-nextto-a-call-for-stiffer-penalties-for-sex-offenders-do-we-learn-more-about-the-media-than-about-human-rights-fromtabloid-coverage-of-human-r/
} 
song and lyrics to end a prefects' sixth form assembly on the power of the press!

\section{Mead set the scene}

The popular press falls foul of correctly reporting on judgments from the European Court of Human Rights (ECtHR). Erroneous reporting includes a disproportionate focus on foreign criminals allegedly asserting their rights, terrorist cases and deportation cases. This has the effect of moral panic; general outrange is fuelled by the idea of unworthy victims utilising human rights. Inaccuracies include deliberately misleading by failing to fully explain the case, distortion of facts and/or outcome and trivialising the victims.

Mead raised questions about the language used to report rights. The Daily Mail regularly uses semiotics to suggest that human rights are a contested concept. One example of this was displayed as the words 'human rights' being placed in quotations. By primarily focusing on human rights claims that readers are led to find 'undeserving' and 'unmerited', tabloids also imply that human rights are not for 'us'. 'What about victims' rights?' challenged one claimant's case and added fuel to the fire that maintains that 'worthy' victims do not evoke rights or need to utilise their rights.

\section{What was the seminar really about?}

The seminar was organised in the light of the looming battle over rights in the UK with the aim of untangling our understanding of the media's role within this debate. This has become increasingly relevant in view of the Conservative Party's plans for the Human Rights Act 1998 that were unveiled to a much more detailed extent at the recent party conference. A variety of mistakes, misconceptions and misrepresentations have been readily circulating in the press and on other media platforms for a number of years. The aim of the seminar was to investigate why these human rights myths and distortions have retained such an intense media focus and evaluate what this tells us about wider perceptions of human rights in the UK.

The seminar began with academic criticism of the approach that the 'tabloid press' uses to report rights issues and judgments. However, speakers and participants questioned how much of this misrepresentation is really explained by wilful agenda. Is it not about the nature of journalism? The disconnection between the elite that implements rights and the general public was shown by Colm O'Cinneide in his paper, 'Separating the Wheat from the Chaff: Distinguishing between the 
Substance and Rhetoric in the 'Turn against Rights'.' A lack of understanding of what rights are, or ought to be, is largely due to public ignorance and an absence of rights education but this is not the fault of the public. The headline grabbing cases build on, as well as motivate the uncertainty that surrounds rights and the gap in general rights discussion. Underlying issues of constitutional importance highlights the urgency for an actual debate that considers the contestation of rights.

\section{From the reporters}

Are the tabloids to blame for this misrepresentation? This is difficult to answer. The extent to which media representation of right and public perception of rights influence each other is blurred. Headlines sell papers but are the papers informing the public, or are the public buying into headlines that fuel their existing opinion?

Owen Bowcott, Legal Affairs Correspondent at The Guardian, gave an interesting insight into the problems encountered by journalists when reporting on human rights issues and cases. Faced with real challenges of deadlines, editorial demands and the political line that the newspaper follows, it is not altogether surprising that rights reporting does not always meet the high expectations of the rights lawyer. Also, due to a decrease in funds, there are very few trained legal correspondents left in journalism, particularly in the tabloid press; Bowcott himself is one of the few remaining in the socalled progressive press. With little or no legal training, it is unsurprisingly difficult for most reporters to fully explain facts and rights issues; for example, the margin of appreciation in relation to implementing rights held in the European Convention on Human Rights. Furthermore, competing with other stories for print space and a limited capacity online naturally leads to a headline grasping spin on the report that may not have otherwise arisen.

\section{Is there a blanket misrepresentation of rights by the media?}

No. International humanitarian events involving a mass disregard for rights evoke sympathetic outrage in all forms of media. However, press reactions to human rights differ in response to domestic and international human rights issues. Human rights abuses abroad that attract press sympathies are those far-removed from day to day life of the audience; the sympathies or anger in response to international human rights violations will not usually result in the usual language or 
campaign-like negative attention that cases involving the UK in the Supreme Court or Strasbourg receive.

Susana Sampaio Dias identified several problems that lead to the favouring of local cases over those emerging from countries abroad. The subject of her research was a Portuguese news channel. Interviewees stated that a genuine lack of monetary funds and audience preferences directed reporters to cover rights stories closer to home. Similarly, Nicky Hawkins from Equally Ours ${ }^{2}$ did identify that rights received positive feedback in local cases. The media discourse on rights represents an extreme, the worst of public opinion, targeted at specific rights, differentiating between victims and superficially qualifying rights. When representing what the tabloids decree as a 'worthy' victim, the public react positively.

Lieve Gies stated that press hostilities to human rights pre-date the so-called 'War on Terror', but the current political climate enables problematic cases to be framed by the characterisation of claimants as deserving or undeserving. Few domestic claimants gain public support; it is a fault of the press to refuse to recognise that human rights are not merely for the angelic, the legitimised victims; they are also for the 'bad', for the criminals.

Rights and victims protected by the Human Rights Act 1998 are not just filed into a hierarchy by the tabloids; the Act is branded to be a criminals' charter. Adam Wagner presented a collection of the most absurd press misrepresentations of human rights. ${ }^{3}$ The tabloids demonstrated 'Catgate' as another 'human rights gone mad' example. Catgate arose when the Home Secretary, Teresa May, announced new immigration policies at the Conservative Party Conference in 2011. She did so on the back of her claim that a pet cat prevented the deportation of 'an illegal immigrant', also stating that she was not 'making it up'! The true reason, however, that aided the applicant in his appeal against deportation to Bolivia included the failing condition of his father; not the presence of a pet cat. The cat merely provided one very minor piece of a great deal of evidence that the applicant was in a stable relationship with his partner and was therefore a very insignificant mention within the case itself.

Unsurprisingly, the Prisoners' Votes saga has also not been portrayed positively by the press. A series of cases starting with Hirst in 2004 (later Hirst v the United Kingdom (No 2) [2005] ECHR 681) led to the ECtHR in Strasbourg ruling that a blanket ban on prisoners voting was outside of the margin of appreciation of the Convention and therefore the UK was in breach. Colin Murray asserted

\footnotetext{
${ }^{2}$ http://www.equally-ours.org.uk/

${ }^{3}$ http://ukhumanrightsblog.com/2014/09/22/the-monstering-of-human-rights/
} 
that Hirst's imprisonment was not punitive but his status within society provided an emotive cypher for wider issues with Strasbourg; leading to the wider questioning of the role of human rights. Strasbourg has become an actor in a political sphere but also this case is another example of the disconnection between the public and the elite. Politicians recognise the importance of rejecting the outcome of this case in favour of growing Euro-scepticism and voters' objections.

\section{Fear over facts}

Ellie Drywood \& Harriet Gray examined rights in the media through the prism of contemporary reaction to asylum and immigration. They discussed negative reporting of migration, abuse of the asylum system, an absence of balance in the press and growing distaste for the 'welfare state' focus on human rights elements of the claim; particularly how this reinforces negative ideas of rights in the UK. Human rights are highlighted or ignored depending on whether the audience is intended to be critical or sympathetic to the claimants in the report. This has a dual effect of trivialising the victim in the case and elevating desired facts as if to create new law.

Do the tabloids and press object to rights when press freedom issues are brought before the ECtHR? Jacob Rowbottom gave some interesting examples of judicial creativity aiding the press, including the so-called progressive press. The press has a history of appealing to Strasbourg prior to the enactment of the Human Rights Act; cases won by press outlets against the UK add to the statistics usually given as evidence to show the 'bad' foreign court telling the government what to do. Mosley v United Kingdom [2011] 53 E.H.R.R. 30, suggests the watchdog role of the press is conditional; the court held that how to legislate on advance warnings of a story before publishing fell within the margin of appreciation of each Member State.

Press freedoms, therefore, do not attract the same criticisms as other cases ruling against the UK from Strasbourg, indicating that the campaign being fought with the charter is just one half of the story. The recent increased criticism against the Human Rights Act, now shifting to the European Convention on Human Rights, plays on Euro-sceptics' dislike of the European Union due to the two often being misrepresented as the same institution. However, more importantly, there is a failure to engage with fundamental criticisms of human rights law.

A real concern of the seminar was that the rights debate, as told by the press, centred on fear alone rather than legal facts. With statistics being used to imply a situation where domestic courts and politicians are being pressured by unpopular foreign judges, the battle lines are effectively being 
drawn between British judges and Strasbourg judges by the tabloid press; for example, the Daily Mail. Time corresponding with the press over factual inaccuracies would be better spent creating a substantive debate surrounding rights. Not all criticisms are based on press inaccuracies but the popular press arguably laid the foundations for politicians to criticise the Human Rights Act. However, these criticisms have yet to break through the superficial fear-inducing misrepresentations as human rights myths to be continuously fought against.

Colm O'Cinneide directed the audience to not over-emphasise the media 'getting it right.' The misrepresentation of rights, cases and institutions cannot be solved simply by reporting every UK judgment, meticulously stating accurate facts. Whether or not this misrepresentation is intentional or not is inconsequential. The press criticism is more generally of the ECtHR and the role the Convention plays in the UK; the ways in which it is criticised is therefore immaterial. Mike Gordon also addressed this topic; the press are fighting a political campaign. Human rights are not merely the judgments that are dealt by the courts. The way human rights are reported is outcome focused, the goal is to win a substantive political debate. Although the many press misrepresentations are important, the underlying issues of the debate are being ignored.

It was clear from the day that debating rights is not objected to by any means; it is to be embraced! However perfectionists are reacting to the many press inaccuracies rather than constructing a constitutional debate on what role human rights play or should play within the UK. A substantive discussion was achieved at the seminar but translating this to the wider sphere by political and media players is somewhat lacking and may prove more difficult. The tabloid attack on rights is set to remain a sustained part of a political campaign that dominates and conceals a more critical discussion on rights and their role in the UK.

Bethany Rodgers, PhD candidate at the University of Liverpool. My broad research area considers the relationship between rights and sovereignty in the United Kingdom.

Email: Bethany.Rodgers@liverpool.ac.uk 